\title{
ザンビア共和国「ンゴンベ」地区の乾燥食品のポリアミン量と 子どもたちのポリアミン推定摂取量
}

\author{
遠 藤 千 鶴 $^{* 1}$, 西 堀 尚 良*1, 後 藤 月 江*1, \\ 光 崎 龍 子*2, 光 崎 研 一*3 \\ *1 四国大学短期大学部生活科学科, *2 麻布大学環境保健学部, *3 麻布大学獣医学部

\section{Polyamine Content of Dried Foods and Estimated Intake by Children in Zambia's Ngombe Region}

\author{
Chizuru Endo *1, Naoyoshi Nishibori ${ }^{* 1}$, Tsukie Goto ${ }^{* 1}$, Ryuko Kohzaki *2 and Kenichi Kohzaki *3 \\ *1 Department of Science for Living, Shikoku University Junior College ; \\ *2 College of Environmental Health, Azabu University ; \\ *3 School of Veterinary Medicine, Azabu University
}

This cooperative support activity was for improving children's nutritional intake in Zambia, and we have already reported on the inadequacy of nutrients in their dietary intake. We estimate in this present experiment the intake and content of polyamine from the dietary survey results.

The results show that beans contained a large amount of spermine, and that small fish contained a large amount of putrescine. In terms of the intake of polyamines contained in food, 8-9-year-old children took in the most spermine contained in solweji beans, while 12 -year-old children took in the most putrescine contained in kapenta.

Dietary guidance should provide an increased polyamine intake through an enhanced protein intake from such foods as solweji beans, soy beans, and kapenta.

Jpn. J. Nutr. Diet., 65 (2) $75 \sim 79$ (2007)

Key words : polyamine, intake, dry food, Zambia

\section{緒言}

我々は世界的にも乳幼児死亡率の高い（18 位/283 カ

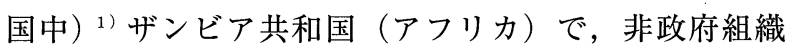
SCDP ( Sustainable Community Development Program) ${ }^{* 1}$ と特定非営利活動法人 TICO（Tokushima International Cooperation) ${ }^{* 2}$ の依頼をうけ，首都ルサ カの低所得者居住地区である「ンゴンベ」における子 どもたちの栄養素摂取量向上のための支援活動に協力 している。この地区に居住する子どもたちの栄養素湶 取量は FAO/WHO の所要量を大幅に下回っており，慢

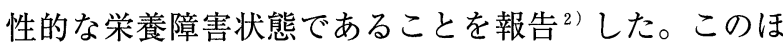
か, 乳幼児死亡率の高い原因としては，HIV/AIDS
の感染，不衛生な飲み水などが考えられるが，特に栄 養障害に起因する免疫力の低下と, それに伴う種々の 感染症への感染が大きな要因であり, 食生活の向上を 目指すことが不可欠であると考えている。そこで，免 疫能に関連のあるポリアミンに注目した。

ポリアミンは広く生物に分布する生体アミンであり, ほとんどすべての生物の細胞内でアルギニンやオルニ チンから合成される物質である。代表的なものに二分 子のアミンを含むプトレスシン，三分子のアミンを含 むスペルミジン，四分子のアミンを含むスペルミンが ある。ポリアミンは細胞増殖に不可欠であり，特定た んぱく質の合成促進 ${ }^{3)}$ や成長期の細胞再生促進 ${ }^{4)} に$ 重

\footnotetext{
キーワード：ポリアミン，旗取量，乾燥食品，ザンビア

（連絡先：遠藤千鶴 ₹ 771-1192 徳島市応神町古川 四国大学短期大学部 電話 088-665-1300（内線 2217） FAX 088-665-8037 E-mail endou-c@shikoku-u.ac.jp)

*1 SCDP（Sustainable Community Development Program）：ザンビア政府保健省の公式な許可を得た公益善意団体。アフリカの中でも干ば つや鉱物輸出の低迷から，社会・経済活動が特に劣悪化し，援助協力の必要性を国際機関より認知されているザンビア共和国の，主に貿困 から脱却できない低所得の人たちを対象に活動している。

*2 TICO (Tokushima International Cooperation) ：1997 年からアフリカのザンビア共和国で, 干ばつに強い村づくり, 筫困地区の民生改善, 救急基盤整備などの国際活動をしている。
} 
要な役割を果たすことが知られており，一方，加齢に 伴う濃度の減少 ${ }^{5)}$ も報告されている。また, 細胞内の ポリアミン含有量は生合成と分解, および細胞外から の取り込みや排泄により調節される。さらに, 食事摂 取によりポリアミンが臟器へ分布することも知られて いる。そのため, 食品中のポリアミン含有量を知るこ とは重要であり, 近年, 食品中のポリアミン含有量や 摄取量が報告4 6) されるようになった。

日常的に摂取食品数が少ない「ンゴンべ」地区では 栄養素摄取不足に伴う免疫能の低下が問題となる。そ のため, 一部の食品のポリアミン含有量を分析し, 子 どもたちの昼食量からその推定摂取量を求め, 食事指 導に役立てる検討をした。

\section{方法}

\section{1. 分析試料}

この地区の一般的な食事内容は前報 ${ }^{2)}$ で報告したよ うに，主食のミルミル（トウモロコシの粉）が摃取食 品のほとんど（ $8 \sim 9$ 割）を占める。そこで分析試料 は主食のミルミルに加え, 主食以外として使用頻度の 高いソルウェジ豆 (インゲンの一種), ピーナッッ, カ ペンタ (乾燥小魚), チェンガ (乾燥小魚), マンゴ, かぼちゃの葉, キノコ, オクラ, 芓虫（乾季はすべて 乾燥) の計 10 種類の乾燥食品（検疫済み）とした。こ れらの食品試料はすべてンゴンべ地区の人々がよく利 用するオープンマーケットで購入した。

\section{2. 食品中のポリアミン分析法}

ポリアミン分析用試料はそれぞれをミルで粉砕後, ふるい（20メッシュ）にかけ， $0.5 \mathrm{~g}$ 前後秤量し， $5 \%$ トリクロロ酢酸中でホモジナイズ（20,000 rpm，20 秒， ハンドホモジナイザー $\mathrm{MH}-1000)$ 後，一定量に定容 した。定容した試料を遠心分離（1,900× $\mathrm{g} ， 10$ 分）し て上清と沈殿物に分け，さらにその沈殿物に $5 \%$ トリ クロロ酢酸を加え, 同様にポリアミンを抽出し定容し た。定容した上清を合一し，セルロースアセテートフ イルター $(0.45 \mu \mathrm{m})$ を用いて濾過後, HPLC で分析し た。カラムはイオン交換カラム（直径 $2.6 \mathrm{~mm} \times 50 \mathrm{~mm}$, 樹脂は日立 No.2619F）を用い，カラム温度は $75{ }^{\circ} \mathrm{C}$ とし た。移動相には緩衝液 $\mathrm{A}$ として $0.045 \mathrm{M}$ クエン酸ナト リウム, $0.061 \mathrm{M}$ クエン酸, $0.064 \mathrm{M}$ 塩化ナトリウム $(\mathrm{pH} 4)$, 緩衝液 B として $0.20 \mathrm{M}$ クエン酸ナトリウム, $2.0 \mathrm{M}$ 塩化ナトリウム（pH7）を使用した。流量は $0.25 \mathrm{ml} / \mathrm{min}$ で, A 液と B 液によるグラジエント溶出を 行った。分離液は $o$-フタルアルデヒド試薬と反応させ, 検出は蛍光分光器（励起波長 $340 \mathrm{~nm}$, 蛍光波長 $435 \mathrm{~nm}$ ) を用いた。ポリアミン標準物質（プトレスシン，スペ ルミジン, スペルミン, カダベリン) は和光純薬工業
(陎より入手し，これらの溶出時間により試料中のポリ アミンを同定した7)。

\section{3. 水分の測定}

水分の測定はポリアミン測定用にミルで粉砕し, ふ るい（20メッシュ）を通した粉末を水分計（Sartorius MA50）を用い， $105{ }^{\circ} \mathrm{C}$ で加熱乾燥して求めた。

\section{4. 調查期間および調查対象者}

我々は「ンゴンべ」での栄養調查を実施するにあた り，ザンビア共和国の保健省より許可を得ている。

調查は 2001 年と 2004 年 8 月の各 4 日間であり, こ の時期は乾季である。本地区は低所得者居住地区であ り，SCDP は栄養失調の子どもをもつ母親を対象に， 子どもの栄養改善と母親の自立を目指した活動として 栄養改善教室を開催している。調查対象者は母親がそ れに参加, あるいは卒業している世帯の $1 \sim 12$ 歳の子 ども 68 名（男 35 名，女 33 名）である。

\section{5. 食事摂取量とポリアミン推定摄取量の算出方法}

食事摂取量は治安のよい昼食時に家庭を訪問し, 調 理開始から食事が終わるまで立ち会い, 秤量法にて子 どもたちの食事摄取重量を計量した。すなわち, 調理 前後の食品重量変化を求めるとともに, 盛り付け量と 残食量の計量から㔖食量を求め, 調理前の食品重量に 換算し, 食品掑取量を求めた。そしてそれらを, 食事 摄取基準に準じた年齢区分で，食品別に平均值で表し た。ポリアミン推定摄取量は分析試料に基づく分析值 に食品摂取量を乗じて求めた。なお，分析できなかっ た生鮮食品（レイプ菜とトマト，卵，玉ねぎ，白菜） については西堀らの分析值 ${ }^{8)}$ を使用して同様に求めた。 炭水化物，たんぱく質，脂質については前報 ${ }^{2}$ で報告 した数值を使用し, 生鮮食品は五訂日本食品標準成分 表の値を使用して推定掑取栄養素量として算出した。

\section{結果}

\section{1. 食品中のポリアミン含有量}

表 1 に乾燥食品のポリアミン分析值と水分量を示し た。植物性食品全てにプトレスシン，スペルミジン， スペルミンが含有され，その中で, マッシュルーム， マンゴ，ミルミル，ピーナッツにはカダベリンも含有 されていた。また, マッシュルーム，かぼちゃの葉， オクラにはプトレスシン，スペルミジンが比較的多く 含まれており，一般的に豆類のポリアミン含有量が高 いことが知られているように,ソルウェジ豆にはスペ ルミンがきわめて多く含まれていることがわかった。

一方, 動物性食品では芋虫, チェンガにプトレスシ ン, スペルミジン, カダベリンが, カペンタにはこれ らの他にスペルミンも含有されていた。特に, 芋虫, カペンタ，チェンガのプトレスシンはそれぞれ $37.8 \pm$ 
表 1 乾燥食品のポリアミン含有量および水分量

\begin{tabular}{|c|c|c|c|c|c|}
\hline & プトレスシン & スペルミジン & スペルミン & カダベリン & 水分量 \\
\hline & $(\mathrm{nmol} / \mathrm{g})$ & $(\mathrm{nmol} / \mathrm{g})$ & $(\mathrm{nmol} / \mathrm{g})$ & $(\mathrm{nmol} / \mathrm{g})$ & $(\% /$ 可食部 $)$ \\
\hline マッシュルーム & $334 \pm 30$ & $819 \pm 29$ & $42 \pm 8$ & $58 \pm 12$ & 13.7 \\
\hline マンゴ & $107 \pm 8$ & $124 \pm 10$ & $18 \pm 3$ & $11 \pm 9$ & 14.0 \\
\hline かぼちゃの葉 & $370 \pm 111$ & $278 \pm 39$ & $21 \pm 5$ & & 13.1 \\
\hline ミルミル & $36 \pm 3$ & $86 \pm 20$ & $100 \pm 30$ & $3 \pm 0$ & 14.0 \\
\hline ソルウェジ豆 & $23 \pm 2$ & $123 \pm 7$ & $1,151 \pm 67$ & & 12.3 \\
\hline オクラ & $264 \pm 20$ & $207 \pm 17$ & $328 \pm 18$ & & 14.1 \\
\hline ピーナッツ & $48 \pm 5$ & $85 \pm 5$ & $57 \pm 9$ & $8 \pm 5$ & 8.1 \\
\hline 芋虫 & $37,817 \pm 2,433$ & $582 \pm 231$ & & $26 \pm 10$ & 9.3 \\
\hline カペンタ & $11,531 \pm 790$ & $426 \pm 127$ & $274 \pm 19$ & $9,379 \pm 409$ & 12.2 \\
\hline チェンガ & $62,335 \pm 2,492$ & $224 \pm 55$ & & $123,060 \pm 3,006$ & 13.6 \\
\hline
\end{tabular}

プトレスシン, スペルミジン, スペルミン, カダベリン : $n=5$

表 2 年齢別食品摂取量（昼食）

\begin{tabular}{|c|c|c|c|c|c|c|}
\hline 年齢 & $\begin{array}{l}1 \sim 2 \text { 歳 } \\
(n=16)\end{array}$ & $\begin{array}{l}3 \sim 5 \text { 歳 } \\
(n=21)\end{array}$ & $\begin{array}{c}6 \sim 7 \text { 歳 } \\
(n=6)\end{array}$ & $\begin{array}{l}8 \sim 9 \text { 歳 } \\
(n=13)\end{array}$ & $\begin{array}{c}10 \sim 11 \text { 歳 } \\
(n=8)\end{array}$ & $\begin{array}{l}12 \text { 歳 } \\
(n=4)\end{array}$ \\
\hline ミルミル（乾燥） & 53 & 86 & 83 & 101 & 61 & 125 \\
\hline ソルウェジ豆（乾燥） & 4 & 7 & 8 & 15 & 6 & 4 \\
\hline ピーナッツ（乾燥） & 3 & 3 & 1 & 1 & 2 & 0 \\
\hline トマト（生） & 9 & 11 & 5 & 7 & 12 & 14 \\
\hline 玉ねぎ（生） & 1 & 2 & 1 & 1 & 1 & 2 \\
\hline 白菜（生） & 4 & 7 & 2 & 5 & 2 & 0 \\
\hline レイプ菜（生） & 18 & 25 & 14 & 15 & 13 & 66 \\
\hline カペンタ (乾燥) & 1 & & & & 1 & 2 \\
\hline 卵（生） & 1 & & & & & \\
\hline 塩 & 0.4 & 0.9 & 0.1 & 0.6 & 0.3 & 0.6 \\
\hline 油 & 1 & 1.7 & 0.1 & 1.4 & 1.9 & 3.2 \\
\hline 棓 & 95.4 & 143.6 & 114.2 & 147.0 & 100.2 & 216.8 \\
\hline
\end{tabular}

表 3 年齢別推定摂取栄養素量（昼食）

\begin{tabular}{lcccccc}
\hline \multicolumn{1}{c}{ 年齢 } & $\begin{array}{c}1 \sim 2 \text { 歳 } \\
(n=16)\end{array}$ & $\begin{array}{c}3 \sim 5 \text { 歳 } \\
(n=21)\end{array}$ & $\begin{array}{c}6 \sim 7 \text { 歳 } \\
(n=6)\end{array}$ & $\begin{array}{c}8 \sim 9 \text { 歳 } \\
(n=13)\end{array}$ & $\begin{array}{c}10 \sim 11 \text { 歳 } \\
(n=8)\end{array}$ & $\begin{array}{c}12 \text { 歳 } \\
(n=4)\end{array}$ \\
\hline 炭水化物 & 60 & 93 & 85 & 109 & 71 & 130 \\
たんぱく質 & 5.2 & 7.2 & 6.4 & 8.5 & 5.9 & 10.8 \\
脂質 & 4.6 & 6.4 & 4.2 & 5.9 & 5.6 & 8.6 \\
\hline
\end{tabular}

$2.4 \mu \mathrm{mol} / \mathrm{g}, 11.5 \pm 0.8 \mu \mathrm{mol} / \mathrm{g}, 62.3 \pm 2.5 \mu \mathrm{mol} / \mathrm{g}$ と, 非常に多く含有されていた。

\section{2. 食事摂取量およびポリアミン推定摂取量}

主食は, トウモロコシの粉であるミルミルに水を加 えて加熱し練りあげた「シマ」と呼ばれるもので, 手 で食べる。食べ方は，「シマ」に炒め煮したカペンタ (日本の煮干しによく似ている)，もしくは炒め煮した レイプ菜, 煮豆を少量つけて一緒に食べる。カペンタ の炒め煮には少量のトマトを入れる世帯が多い。副菜 の材料はカペンタ, チェンガ, ソルウェジ豆, レイプ 菜がよく使用され，卵，ピーナッツ，玉ねぎ，トマト
は味付け程度にしか使用されず，摂取食品数は 4 〜 品と少ない。食事内容はどの世帯でもよく似ており, 年齢別の食品摂取量は表 2 に示したように少ない。ま た, 推定捸取栄養素量についても炭水化物, たんぱく 質, 脂質ともに少ない（表 3 ）。これらの食事量から, ポリアミン摂取量を年齢別に推定算出（表 4）したと ころ, 8〜9歳児にスペルミンの摂取が多かった。これ らはソルウェジ豆の摂取によるものと考えられる。ま た，12 歳児のプトレスシンの摂取が他の年齢に比べ多 かったのは，カペンタの摂取によるものである。 
表 4 昼食のポリアミン推定摂取量

\begin{tabular}{cccc}
\hline 年齢 (歳) & プトレスシン & スペルミジン & スペルミン \\
\hline $1 \sim 2$ & 12.4 & 8.1 & 10.5 \\
$3 \sim 5$ & 5.5 & 12.1 & 17.5 \\
$6 \sim 7$ & 4.2 & 10.0 & 17.3 \\
$8 \sim 9$ & 5.3 & 12.8 & 27.6 \\
$10 \sim 11$ & 16.5 & 8.6 & 14.3 \\
12 & 36.0 & 20.3 & 19.4 \\
\hline
\end{tabular}

\section{考}

\section{察}

「ンゴンベ」の人々は地区内にあるオープンマーケ ットで食品を購入する。そこではミルミルは袋詰めで, その他の食品は大きなザルに盛り上げられた状態で販 売されている (写真)。分析結果では, 芋虫, カペンタ, チェンガにプトレスシンが多く含有されていた。プト レスシンは, 日本では魚介類や食肉類などたんぱく質 を主とする食品腐敗度を示す不揮発性腐敗アミン ${ }^{9)}$ して使用されており，プトレスシン含有量が大きくな るほど腐敗が進んでいることになる。日本の者干し （かたくちいわし）のプトレスシン含有量を測定すると $302 \pm 34 \mathrm{nmol} / \mathrm{g}$ であり，分析に用いた 3 種の動物性食 品に比べ少なかった。このことから，分析した 3 種の 動物性食品は乾燥食品であるにもかかわらず，保存状 態が悪かったのではないかと考えられる。

プトレスシンは腸内にある酵素，ジアミンオキシダ 一ゼによりほとんどが分解されるため，プトレスシン としては摄取量の $10 \%$ 程度しか吸収されないが，スぺ ルミジン，スペルミンは分解されないため，その $80 〜$ $90 \%$ \%゙そのまま吸収される4)。体内ではプトレスシン からスペルミジン，スペルミンが合成されることから プトレスシンはこれらポリアミンの前駆体として重要 である。ザンビア共和国の芋虫, カペン夕, チェンガ は保存状態に問題があると考えられるものの, きわめ

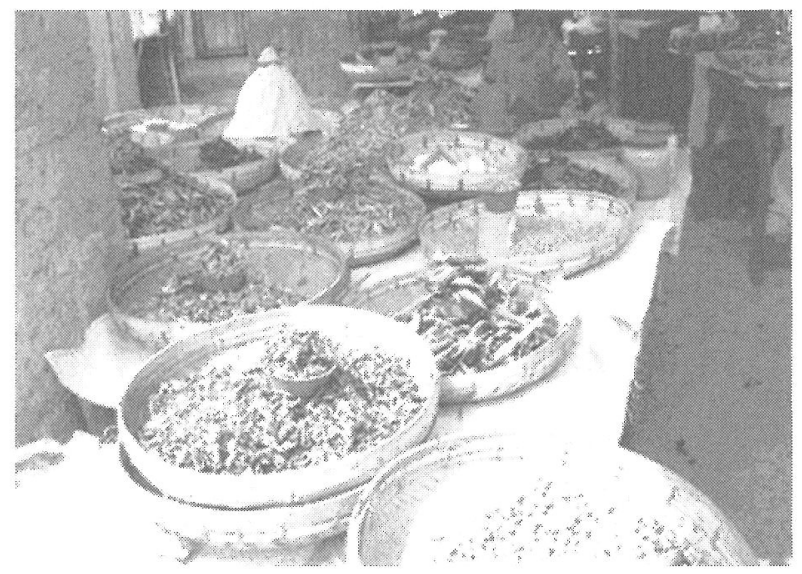

写真 オープンマーケットの食品販売
て多量のプトレスシンが含まれており，これらの食品 の摂取はポリアミン代謝と体内のポリアミン含有量に 影響を与えると考えられる。

食事調査から判断した子どもたちの食品摄取量は非 常に少なく，その摂取量から算出した炭水化物，たん ぱく質の撕取も少ない。従って，エネルギー，たんぱ く質の確保が基本的に重要なことである。またザン ビア共和国では砂糖にビタミンAが，塩にヨードが添 加されているがいずれも摂取量は少なく，ビ夕ミン類， ミネラルの掑取量を増加させることも重要である。

食糧事情はその国の経済事情，気候による農作物の 収檴量の変化などに大きく影響される。さらに、ザン ビア共和国は1963 年までイギリスの統治下にあり，そ の間ザンビア共和国の人々にはたんぱく質を補うため に大豆が配給されていた歴史がある。そのため，ザン ビア共和国の人々にとって大豆は配給物というイメー ジがあり，進んで摄取しないという悪い慣習が残って いる。今回の食事調查でもソルウェジ豆料理はあって も大豆の料理はみられなかった。ソルウェジ豆は前報21 に報告した赤豆であり，100g 中に $26.2 \mathrm{~g}$ のたんぱく質 を含有している。また，一般によく摂取されるカペン 夕，チェンガなどの小魚の調理法はいわゆる炒め煮で ある。料理は離乳食や幼览食として作られてないこと などもあり，固く食べにくいことから，子どもたちに よるこれらの食品の摂取量が低くなったと思われる。

栄養改善教室では，たんぱく質含有量の多い大豆の 撖取を勧めるために大豆や大豆粉を使用した料理講習 会を行っている。今回のポリアミン分析で, ソルウェ ジ豆には体内での吸収がよいスペルミンが多く含まれ ていることがわかったため，食事指導に役立つと思わ れる。併せて，カペンタやチェンガなどを用いた，乳 幼児向き調理法の紹介を取り入れた食事指導により， 子どもたちのたんぱく質摂取量の改善が進めば，ポリ アミン摂取量も増加する可能性が高く, それによる免 疫細胞の活性化に期待できると考えられる。

\section{ま と め}

我々はザンビア共和国「ンゴンベ地区」で，子ども たちの栄養素摂取量の向上のための支援活動に協力し ている。これまでに子どもたちの食事調査で摂取栄養 素量の少ないことを報告してきた。本実験では，こ水 らの食事調査から食品のポリアミン含有量とポリアミ ンの摂取量を推定した。

その結果，ソルウェジ豆にはスペルミンが，小魚類 にはプトレスシンが多く含まれていた。子どもたちの 食事に含まれるポリアミン推定摂取量は，8～9 歳览に スペルミンの摂取が多く，これらはソルウェジ豆の摂 
取によるものであった。また，12 歳児のプトレスシン の摂取が他の年齢に比べて多かったのは，カペンタの 摃取によるものであった。

栄養改善教室に扔いて食事指導する場合, ソルウェ ジ豆，大豆，およびカペンタなど小魚類のたんぱく質 摂取を強化することにより，ポリアミン摄取量の増加 が期待できると思われる。

\section{文}

\section{献}

1) UNICEF : The State of the World's Children 2006, p.97 (2005) UNICEF, New York

2）大福月江，井形和枝，遠藤千鶴：ザンビア低所得 者居住区の食環境と幼児・学童児の昼食摄取に関する 調查，栄養学雑誌，60，99-105（2002）

3）五十嵐一衛，柏木恵子：神秘の生命物質ポリアミ ン, 化学と生物, 34 442-450（1997）

4) Bardocz, S., Duguid, T. J., Brown, D. S., Grant, G., Pusztai, A. and White, A. : The importance of dietary polyamines in cell regeneration and growth, Br. J. Nutr., 73, 819-828 (1995)
5) Nishimura, K., Shiina, R., Kashiwagi, K. and Igarashi, K.: Decrease in polyamines with aging and their ingestion from food and drink, J.Biochem., 139, 81 -90 (2006)

6) Okamoto, A., Sugi, E., Koizumi, Y., Yanagida, F. and Udaka, S. : Polyamine content of ordinary foodstaffs and various fermented foods, Biosci. Biotech. Biochem., 61, 1582-1584 (1997)

7) Nishibori, N. and Nishijima, T. : Changes in polyamine levels during growth of a red-tide causing phytoplankton Chattonella antiqua (Raphidophyceae), Eur. J. Phycol., 39, 51 - 55 (2004)

8) Nisibori, N., Fujihara, S. and Akatuki, T. : Amounts of polyamines in foods in Japan and intake by Japanese, Food Chem., in press.

9）厚生労働省監修: 食品衛生検查指針, 理化学編, pp.621-630（2005）日本食品衛生協会, 東京

(受付：平成 18 年 9 月 20 日, 受理 : 平成 19 年 2 月 17 日) 